\title{
PEMBARUAN PENDIDIKAN ISLAM MENURUT MUHAMMAD ABDUH
}

\section{Andik Wahyun Muqoyyidin}

Fakultas Agama Islam Universitas Pesantren Tinggi Darul Ulum Jombang

Komplek PP. Darul Ulum Peterongan Jombang 61481

Email: andikwahyun_m@yahoo.com

\section{ABSTRAK}

Tulisan ini hendak mengurai pemikiran Muhammad Abduh mengenai pembaruan pendidikan Islam. Pendekatan yang digunakan adalah analisis tokoh dan wacana. Hasil penelaahan atas sejumlah buku teks menunjukan bahwa pembaruan pendidikan Muhammad Abduh diawali dengan memformulasikan fondasi baru epistemologis keyakinan umat Muslim melalui Tajdîd al-Fahm (memperbarui pemahaman Islam). Artinya nilai dan prinsip dasar keberagamaan Islam yang esensial saja yang perlu dipertahankan sedangkan aspek historisitas kelembagaannya harus diaktualkan sebab ia meruang dan mewaktu mengikuti perubahan zaman. Dalam konteks pendidikan, Abduh menerapkan prinsip di atas dengan cara menghilangkan dualisme dalam pendidikan bahwa sekolah umum harus dapat memberikan pelajaran agama dan sekolah agama harus mampu mengembangkan ilmu pengetahuan. Dalam penyusunan materi pun harus seimbang antara pemenuhan kebutuhan akal dengan jiwa guna mencapai kebahagiaan dunia dan akhirat.

Kata Kunci: Modernisasi, Pembaruan, Pendidikan Islam

\section{ABSTRACT}

This paper is to explore Muhammad Abduh's thought regarding Islamic education form. The approach used is discourse and figure analysis. The result of the studies towards a number of textbooks shows that education reform by Muhammad Abduh was initialized by formulating foundation the epistemology of Muslim beliefs throught Tajdid al-Fahm (Renewal Islamic Understanding). It meanas that the basic values and principles of variety in Islam are only about the essence that need to be maintained. While the aspect of institutional bistoricity should be maintained actual fit with the present time, context, and world dynamic. In the context of education, Abduh implemented the priciples above by omitting dualism in education. The principle is that public school should provide religion leason and religion achool asould develope the knowledge. In organizing the materials, the fulfillments to brain and should needs should be kept balanced.

Keywords: Modernization, Renewal, Islamic Education. 


\section{PENDAHULUAN}

Sepanjang sejarah peradaban Islam, ada dua corak pemikiran yang selalu memengaruhi cara berpikir umat Islam. Pertama, pemikiran tradisionalis (orthodox) yang bercirikan sufistik; dan kedua, pemikiran rasionalis yang bercirikan liberalis, terbuka, inovatif dan konstruktif. Kedua corak itu sesungguhnya nampak pada masa kejayaan Islam. Keduanya bersatu padu, saling mengisi satu sama lain. Saat itu umat Islam tidak membeda-bedakan mana yang lebih utama harus mereka pelajari. Baik ilmu agama yang bersumber dari wahyu maupun ilmu pengetahuan yang bersumberkan nalar, mereka pelajari tanpa ada dikotomi. Keduanya telah betul-betul dijadikan sebagai sarana dalam menggali ilmu, baik ilmu agama maupun ilmu pengetahuan umum. Kejayaan ini berlangsung cukup lama, sampai diangkatnya penguasa baru Abbasiyyah-al-Mutawakkil-yang bermadzhab sunnî melakukan pencabutan izin resmi Mu'tazilah sebagai satu aliran resmi kenegaraan yang pernah terjadi pada masa al-Ma'mun. Kondisi ini terus berlanjut hingga umat Islam secara umum merasa antipati terhadap golongan Mu'tazilah, yaitu golongan yang gencar menyebarkan ajaran rasionalis. Sejak itu masyarakat tidak lagi mau mendalami ilmu-ilmu sains dan filsafat. Pemikiran logis dan ilmiah tidak lagi menjadi budaya berpikir masyarakat muslim sampai akhirnya pola berpikir rasional berubah menjadi cara berpikir tradisional yang banyak dipengaruhi oleh ajaran spiritualitas, takhayul dan kejumudan (Asrahah, 1999: 123).

Antipati terhadap Mu'tazilah juga telah menyebabkan pengawasan yang ketat terhadap penerapan kurikulum di madrasah. Jatuhnya paham Mu'tazilah telah mengangkat kaum konservatif menjadi kuat. Dalam rangka mengembalikan paham abl as-sunnah sekaligus memperkokoh basis kelompoknya, para ulama sering melakukan kontrol terhadap kurikulum di lembaga-lembaga pendidikan. Pada masa ini, materi pelajaran sangat minim, hanya terbatas pada ilmu-ilmu agama, bahkan pendidikan Islam lebih identik dengan pengajaran tashawwuf dan fiqih. Kondisi yang demikian itu terus diperburuk seiring dengan runtuhnya kota Baghdad, akibat serangan tentara Mongol pada tahun $1258 \mathrm{M}$, yang kemudian berakibat pada kehancuran kebudayaan dan pusat pendidikan Islam. Artinya, kemunduran umat Islam sesungguhnya telah diawali sejak runtuhnya aliran Mu'tazilah, yang kemudian berakibat pada cara berpikir umat Islam yang tidak lagi rasional, tidak lagi mau menganggap ilmu pengetahuan umum sebagai satu kesatuan ilmu yang punya nilai guna. Hal ini terus diperburuk oleh situasi politik negeri Islam yang tidak menentu, yang berakibat pada rapuhnya sistem pemerintahan saat itu, yang kemudian juga berakibat pada lemahnya sektor pendidikan, baik institusi maupun metodologi, bahkan tujuan pendidikan Islam semakin kehilangan visi, misi dan tujuan sebagaimana yang pernah diterapkan di masa-masa kejayaan Islam. Umat Islam tidak akan dapat ke luar dari belenggu keterpurukan, kecuali mereka mau mengubah cara pandang mereka terhadap agamanya sendiri dan sekaligus terhadap agama orang lain. Tentu mengubah sesuatu yang sudah terlanjur "kronis" ini harus dimulai dari sesuatu yang paling 
mendasar, yaitu metodologi kritis yang betul-betul sesuai dengan kebutuhan dan tuntutan zaman yang dengan sifat "kritis" tersebut diharapkan dapat membongkar (tafkik) dogma dan ortodoksi dalam tubuh umat Islam (Muqoyyidin, 2012: 1833).

Secara makro, eksistensi pendidikan Islam senantiasa berbaur dengan realitas yang mengitarinya. Dalam perspektif historis, pembauran antara pendidikan Islam dengan realitas sosio-kultural menemui dua kemungkinan: Pertama, pendidikan Islam memberikan pengaruh terhadap lingkungan sosiokultural, dalam arti memberikan wawasan filosofis, arah pandangan, motivasi perilaku dan pedoman perubahan sampai terbentuknya suatu realitas sosial baru (Abu Bakar, 2012: 136). Sebagai contoh dari kemungkinan pertama tersebut dapat dilihat pada Gerakan Modernisasi Muhammad Abduh awal abad XX di Mesir. Kedua, pendidikan Islam dipengaruhi oleh realitas perubahan lingkungan sosio-kultural tersebut, dalam arti penentuan sistem pendidikan, institusi dan pilihan-pilihan prioritas sangat bergantung pada eksistensi, aktualisasi dan cara pandang umat Islam terhadap dirinya sendiri (Azra, 2000: 64).

Umat Islam pada masa sekarang menghadapi tantangan yang berat dari pihak luar yang berimplikasi terhadap masa depan kehidupan beragamanya. Tantangan itu mulai dari kolonialisme dan imperialisme yang menghasilkan benturan keras antara kebudayaan Barat dengan ajaran/nilai-nilai Islam, sampai kepada materialisme, kapitalisme dan industrialisme yang telah berhasil mengubah sistem berpikir dan struktur sosial secara global (Baidlawi, 2006: 160). Datangnya era industrialisasi merupakan keniscayaan yang tidak bisa dipungkiri oleh siapapun, meski sebagian kecil masyarakat menolaknya. Di kalangan masyarakat Muslim, era industrialisasi direspons secara beragam; sebagian dari mereka menyambut positif, sementara itu sebagian lainnya menolak secara tidak kritis atas logika di balik proses industrialisasi itu. Suka atau tidak, cepat atau lambat, umat Muslim pada akhirnya harus menerima dan hidup bersama di era ini (Hilmy, 2012: 1).

Bagi umat Islam, kehidupan modern dengan industrialisasinya sebagai penopang utama memiliki relasi yang cukup rumit dan menantang (Gellner, 1981: 96 dan Ahmed, 1999: 117). Pertama, pola relasi di antara keduanya menimbulkan respons dan reaksi yang cukup beragam, mulai dari resistensi hingga akomodasi. Ia tidak jarang dipersepsi secara diametral dalam oposisi biner yang saling bertentangan dan menegasikan satu sama lain (Gellner, 1985: 43). Hal ini terjadi manakala industrialisasi diyakini bukan berasal dari Islam, atau Islam tidak memiliki nucleus kehidupan industri. Industri dan proses industrialisasi dalam konteks ini, dipahami sebagai sebuah konsep dan praktik non-Islam, terutama Barat, yang membawa implikasi-implikasi nilai yang khas Barat. Industrialisasi pada gilirannya dianggap hanya akan menggerus identitas keberagamaan dan meluruhkan nilai-nilai Islam. Jika ini yang terjadi, sikap yang dimunculkan oleh umat Islam atas industrialisasi niscaya bersifat resisten atau perlawanan. 
Spektrum kedua diisi oleh individu-individu yang memilih akomodatif terhadap industri dan industrialisasi, melalui penerimaan secara total atas industrialisasi sebagai jalan menyejahterakan umat manusia. Namun yang perlu dicatat adalah, jika sikap yang hendak dibangun komunitas Muslim bersifat akomodatif-responsif terhadap industrialisasi, acapkali mereka mengalami kesulitan besar ketika hendak merumuskan bagaimana cetak-biru industrialisasi yang relevan bagi pola kehidupan Muslim dengan segala atribut, karakter dan identitas keberagamaannya (Hilmy, 2012: 4). Sebagai respons atas tantangan tersebut, para pemikir dan intelektual muslim melancarkan berbagai upaya modernisasi yang muncul dalam berbagai ragam dan karakteristiknya. Hal ini sesuai dengan setting sosio-historis yang melingkupi para modernis (Baidlawi, 2006: 161). Dalam konteks ini, pendidikan Islam menjelma menjadi sarana yang paling ampuh dan utama untuk mengupayakan modernisasi itu secara lebih kritis dan sistemis. Melalui pendidikan Islam, transfer nilai-nilai dan ajaran Islam dapat dilakukan secara terencana dan sistematis.

Modernisasi pendidikan Islam adalah salah satu pendekatan untuk suatu penyelesaian jangka panjang atas berbagai persoalan umat Islam saat ini dan pada masa yang akan datang. Oleh karena itu, modernisasi pendidikan Islam adalah sesuatu yang penting dalam melahirkan sebuah peradaban Islam yang modern (Husein dan Ashraf, 1994: 6). Namun demikian, modernisasi pendidikan Islam tidak dapat dirasakan hasilnya pada satu dua hari saja melainkan memerlukan suatu proses yang panjang yang setidaknya akan menghabiskan sekitar dua generasi. Mengingat pentingnya modernisasi pendidikan Islam, maka setiap lembaga pendidikan Islam harus mendapatkan penanganan yang serius, setidaknya ini untuk menghasilkan para pemikir dan intelektual yang handal dan mempunyai peran sentral dalam pembangunan.

Tulisan ini bermaksud mengurai pemikiran modernisasi pendidikan Islam, dalam perspektif Muhammad Abduh. Gerakan awal kebangkitan Islam mengalami signifikansinya pada figur Muhammad Abduh (1849-1905). Pembaruan yang digagas Muhammad Abduh mempunyai dampak yang luas dan menentukan terhadap perjalanan mutakhir sejarah Islam. "Modernisasi" dan "modernisme" Abduh itu, termasuk dalam bidang pendidikan, tidak dapat dipahami secara lebih tepat, ketika tidak ditelusuri latar belakang umum keadaan umat Islam dan bangsa Arab terutama saat menjelang akhir abad kesembilan belas. Tulisan ini juga berupaya mengapresiasi reaksi sejumlah kelompok terhadap usaha-usaha pembaruan Muhammad Abduh yang sedemikian keras. Padahal pembaruannya itu sedemikian bermakna, terutama ketika semua upayanya itu diproyeksikan terhadap keterbelakangan yang membelenggu umat Islam, khususnya bangsa Arab (bukan bangsa Turki dan Iran), pada saat-saat menjelang Abduh melancarkan gerakannya (Madjid, 2008: 358-359). 


\section{PEMBAHASAN}

Syaikh Muhammad Abduh nama lengkapnya adalah Muhammad bin Abduh bin Hasan Khairullah. Dia dilahirkan di desa Mahallat Nashr di Kabupaten al-Buhairah, Mesir pada tahun 1849 M. Dia berasal dari keluarga yang tidak tergolong kaya, bukan pula keturunan bangsawan. Ayahnya dikenal sebagai orang terhormat yang suka memberi pertolongan (Shihab, 2006: 6). Ayahnya bernama Abduh bin Hasan Khairullah, sementara ibunya yang bernama Junaynah, seorang janda yang mempunyai silsilah dengan Umar bin Khathab yang berasal dari sebuah desa di propinsi Gharbiyah (Firdaus, 1979: 17). Kelahiran Abduh bersamaan dengan masa ketidakadilan dan ketidakamanan di Mesir yang dijalankan oleh pemerintah. Ketika itu Mesir berada di bawah kekuasaan Muhammad Ali Pasya. Sebagai penguasa tunggal ia tidak mengalami kesukaran dalam mewujudkan program-program pemerintahannya di Mesir, terutama dalam bidang pendidikan, ekonomi dan militer. Ia adalah raja absolut yang menguasai sumber-sumber kekayaan terutama tanah, pertanian dan perdagangan. Di daerah-daerah, para pegawainya juga bersikap keras dalam melaksanakan kehendak dan perintahnya. Rakyat merasa tertindas. Untuk mengelakkan kekerasan yang dijalankan oleh pemerintah, rakyat terpaksa berpindah-pindah tempat tinggal. Ayah Abduh sendiri termasuk salah seorang yang tidak setuju dan menentang kebijakan pemerintah yang tiran itu. Salah satu dari kebijakan pemerintah yang ditentang oleh ayah Abduh adalah tingginya pajak tanah (Hasaruddin, 2012: 335).

Mula-mula Muhammad Abduh dikirim oleh ayahnya ke Masjid al-Ahmadi Thantha (sekitar $80 \mathrm{~km}$ dari Kairo) untuk mempelajari tajwid al-Qur'an. Namun, sistem pengajaran di sana dirasakan sangat menjengkelkannya sehingga setelah dua tahun (tahun 1864) di sana, Muhammad Abduh memutuskan untuk kembali ke desanya dan bertani seperti saudara-saudara serta kerabatnya. Waktu kembali ke desa inilah dia dinikahkan (Nasution, 1987: 12). Walaupun sudah menikah, ayahnya tetap memaksanya untuk kembali belajar. Namun, Muhammad Abduh sudah bertekad untuk tidak kembali. Dia lari ke desa Syibral Khit. Di sana banyak paman dari pihak ayahnya menetap dan bertempat tinggal. Di kota ini dia bertemu dengan Syaikh Darwisy Khidr, salah seorang pamannya yang mempunyai pengetahuan mengenai al-Qur'an dan menganut paham tasawuf asySyadziliah. Sang paman berhasil mengubah pandangan pemuda Muhammad Abduh, dari seseorang yang membenci ilmu pengetahuan menjadi orang yang menggemarinya.

Dari Thantha, Muhammad Abduh menuju ke Kairo untuk belajar di alAzhar, yaitu pada bulan Februari 1866. Sistem pengajaran di kampus ini, ketika itu tidak berkenan di hatinya, karena menurut Abduh: "Kepada para mahasiswa hanya dilontarkan pendapat-pendapat para ulama terdahulu tanpa mengantarkan mereka pada usaha penelitian, perbandingan dan penarjihan." Namun, di perguruan ini dia sempat berkenalan dengan sekian banyak dosen yang dikaguminya, antara lain; (1) Syaikh Hasan ath-Thawil, yang mengajarkan kitab- 
kitab filsafat karangan Ibnu Sina dan logika karangan Aristoteles. Padahal kitabkitab tersebut tidak diajarkan di al-Azhar pada waktu itu, (2) Muhammad alBasyumi, seorang yang banyak mencurahkan perhatian dalam bidang sastra dan bahasa, bukan melalui pengajaran tata bahasa, melainkan melalui kehalusan rasa dan kemampuan mempraktikannya (Shihab, 2006: 9). Pada saat itu, Syaikh Darwisy kembali tampil demi membangkitkan semangat Abduh untuk kembali belajar di tempat yang sama. Kali ini bukan lagi hanya belajar materi agama seperti fiqih, tauhid dan semacamnya, tetapi juga mempelajari logika, matematika dan sains (Nasution, 1987: 13). Pengalaman ini menjadikan Abduh sangat toleran dan bebas berpikir, yakni suatu sikap berpikir yang masih jarang ditemukan ketika itu.

Pada tahun 1871, Jamaluddin al-Afghani tiba di Mesir. Afghani di samping sebagai tokoh terkenal di Mesir, juga dikenal sebagai penggagas kebebasan berpikir dalam bidang agama dan politik. Kehadirannya disambut oleh Muhammad Abduh dengan menghadiri pertemuan-pertemuan ilmiah yang diadakan oleh al-Afghani. Perjumpaannya dengan Afghani ini, mempunyai implikasi yang sangat besar bagi perkembangan pemikiran rasional Abduh (Firdaus, 1979: 18; Ali, 1990: 13). Setelah dua tahun sejak pertemuannya dengan Jamaluddin al-Afghani, terjadilah perubahan yang sangat berarti pada kepribadian Abduh, dan mulailah dia menulis kitab-kitab, seperti Risâlat al'Aridah (1873), disusul kemudian dengan Hasyiat Syarh al-Jalâl ad-Dawwâni li alAqầid adh-Adhûdhiyah (1875). Abduh, yang ketika itu baru berumur 26 tahun, telah menulis dengan mendalam tentang aliran-aliran filsafat, ilmu kalam (teologi) dan tasawuf serta mengkritik pendapat-pendapat yang dianggapnya salah. Di samping itu, Abduh juga menulis artikel-artikel pembaruan di surat kabar al-Ahrâm, Kairo. Melalui media ini, gema tulisan tersebut sampai ke telinga para pengajar di al-Azhar yang sebagian besar tidak menyetujuinya. Namun, berkat kemampuan ilmiahnya serta pembelanya, Syaikh Muhammad al-Mahdi alAbbasi, yang ketika itu menduduki jabatan "Syaikh al-Azhar", Muhammad 'Abduh dinyatakan lulus dengan mencapai tingkat tertinggi di al-Azhar (Ridha, 1931: 102-103). Ketika itu, Abduh dalam usia 28 tahun (1877 M).

Setelah lulus dari tingkat Alamiyah (sekarang L.C.), dia mengabdikan diri pada al-Azhar dengan mengajar Manthiq (logika) dan ilmu al-Kalam (Teologi), sedangkan di rumahnya dia mengajar pula kitab Tahdzî́b al-Akblâq, karangan Ibnu Miskawaih serta Sejarab Peradaban Kerajaan-Kerajaan Eropa. Pada tahun 1878, Muhammad Abduh diangkat sebagai pengajar "Sejarah" pada Sekolah Dâr alUlûm (yang kemudian menjadi fakultas) serta ilmu-ilmu Bahasa Arab pada Madrasat al-Idârah wa al-Alsun (Sekolah Administrasi dan Bahasa-Bahasa) yang didirikan Khedive (Rahman, 1985: 78). Pada tahun 1879, Jamaluddin al-Afghani diusir oleh pemerintah Mesir atas hasutan Inggris yang ketika itu sangat berpengaruh di Mesir. Sedangkan Muhammad Abduh pada tahun yang sama diberhentikan dari kedua sekolah yang disebut terakhir dan diasingkan ke tempat kelahirannya, Mahallat Nashr (Mesir). Tetapi dengan terjadinya perubahan 
kabinet pada 1880, Abduh dibebaskan kembali dan diserahi tugas memimpin surat kabar resmi pemerintah, yaitu al-Waqâ'i al-Mishriyah. Surat kabar ini, oleh Muhammad Abduh dan kawan-kawannya, bekas murid al-Afghani, dijadikan media untuk mengkritik pemerintah dan aparat-aparatnya yang menyeleweng atau bertindak sewenang-wenang.

Setelah Revolusi Urabi 1882 (yang berakhir dengan kegagalan), Muhammad Abduh, yang ketika itu masih memimpin surat kabar al-Waqâंi, terlibat dalam revolusi, sehingga pemerintah Mesir memutuskan untuk mengasingkannya selama tiga tahun dengan memberi hak kepadanya memilih tempat pengasingannya. Akhirnya, dia memilih Suriah. Di negara ini, Muhammad Abduh menetap selama setahun. Kemudian dia menyusul gurunya Jamaluddin al-Afghani, yang ketika itu berada di Paris. Dari sana mereka berdua menerbitkan surat kabar al-'Urwat al-Wutsqâ, yang bertujuan mendirikan panIslam serta menentang penjajahan Barat, khususnya Inggris. Secara umum jurnal ini merupakan jurnal mingguan politik, yang melaporkan dan memberi gambaran tentang keadaan politik dan perjuangan umat Islam di negara-negara Islam untuk melepaskan diri dari dominasi luar, dengan tujuan menyatukan mereka. Menurut Ahmad Amin, sebenarnya jiwa dan pemikiran yang tertuang dalam jurnal tersebut berasal dari gurunya, sementara tulisan yang mengungkapkan jiwa dan pemikiran tersebut adalah dari Abduh (Amin, 1960: 49). Dengan demikian, 'Abduh pada hakikatnya tidak mempunyai jiwa revolusioner, namun ia cenderung menjadi pemikir dan pendidik sebagaimana terlihat dari kegiatannya baik ketika di Beirut maupun di Mesir. Abduh ingin mengadakan perubahan dan pembaruan Islam melalui pendidikan dan budaya bukan melalui revolusi (Ali, 1990: 105-106).

Pada tahun 1885, setelah terbit 18 kali, jurnal ini dilarang beredar di Eropa (Nasution, 1987: 20) maka Abduh meninggalkan Paris menuju Beirut (Lebanon) dan mengajar di sana sambil mengarang kitab-kitab: (1) Risâlat at-Taubîd (dalam bidang teologi); (2) Syarh Nabjil Balâghah (komentar menyangkut kumpulan pidato dan ucapan Imam Ali bin Abi Thalib); (3) Menerjemahkan kitab karangan Jamaluddin al-Afghani, ar-Raddu 'Alâ ad-Dabriyyîn (bantahan terhadap orang yang tidak mempercayai wujud Tuhan) dari bahasa Persia; dan (4) Syarh Maqâmât Bad̂̀" az-Zamân al-Hamazani (kitab yang menyangkut bahasa dan sastra Arab). Dalam Risâlat at-Taubîd, Abduh mengemukakan kembali beberapa tesis fundamental dari kalâm sunnî abad pertengahan, dengan penekanan baru dan menghidupkan kembali rasionalisme (Rahman, 1985: 118).

Di Beirut, aktivitas Muhammad Abduh tidak terbatas pada mengarang dan mengajar saja, tetapi bersama beberapa tokoh agama lainnya, dia juga mendirikan suatu organisasi yang bertujuan menggalang kerukunan antar umat beragama. Organisasi ini telah membuahkan hasil-hasil positif, terbukti dengan dimuatnya artikel-artikel yang sifatnya menonjolkan ajaran-ajaran Islam secara objektif pada media massa di Inggris, padahal ketika itu, jarang sekali dijumpai hal serupa di media Barat. Namun, organisasi ini dan aktivitas-aktivitas anggotanya dinilai oleh 
penguasa Turki di Beirut mempunyai tujuan-tujuan politik, sehingga penguasa tersebut mengusulkan kepada pemerintah Mesir untuk mencabut hukuman pengasingan Muhammad Abduh agar dia segera kembali ke Mesir (Shihab, 2006: 12).

Pada tahun 1888, Muhammad Abduh kembali ke tanah airnya dan oleh pemerintah Mesir diberi tugas sebagai hakim di Pengadilan Daerah Banha. Walaupun ketika itu Muhammad Abduh sangat berminat untuk mengajar, namun pemerintah Mesir agaknya sengaja merintangi, agar pikiran-pikirannya yang mungkin bertentangan dengan kebijakan pemerintah ketika itu, tidak dapat diteruskan kepada putra-putri Mesir. Tahun 1894, Abduh diangkat menjadi salah satu anggota panitia di al-Azhar. Posisi ini dipergunakan oleh Abduh untuk merealisasikan ide-ide pembaruannya. Namun perlawanan dari para ulama tradisional, membuatnya harus bekerja lebih keras lagi (Firdaus, 1979: 21). Pada 1905, Muhammad Abduh mencetuskan ide pembentukan Universitas Mesir. Ide ini mendapat tanggapan yang antusias dari pemerintah maupun masyarakat, terbukti dengan disediakannya sebidang tanah untuk tujuan tersebut. Namun universitas yang dicita-citakan ini baru berdiri setelah Muhammad Abduh berpulang ke Rahmatullah dan universitas inilah yang kemudian menjadi "Universitas Kairo". Pada tanggal 11 Juli 1905, pada masa puncak aktivitasnya membina umat, Muhammad Abduh meninggal dunia di Kairo, Mesir. Mereka yang menangisi kepergiannya bukan hanya umat Islam tetapi ikut pula berduka sekian banyak tokoh non-Muslim (Shihab, 2006: 13).

\section{Modernisasi Pendidikan Islam}

Secara etimologis, modernisasi berasal dari kata modern, yang telah baku menjadi bahasa Indonesia dengan arti pembaruan. Oleh karena itu, modernisasi juga bisa disebut dengan pembaruan. Dalam masyarakat Barat "modernisasi" mengandung arti pikiran, aliran, gerakan dan usaha-usaha untuk mengubah paham-paham, adat istiadat dan institusi-institusi lama, agar semua itu menjadi sesuai dengan pendapat-pendapat dan keadaan baru yang ditimbulkan oleh ilmu pengetahuan dan teknologi modern (Nasution, 1997: 181). Lahirnya modernisasi atau pembaruan di sebuah tempat akan selalu beriringan dengan kemajuan ilmu pengetahuan dan teknologi yang berkembang saat itu. Artinya, tidak mungkin akan ada pembaruan tanpa ada dukungan perkembangan ilmu pengetahuan dan teknologi.

Agar pemahaman tentang modernisasi atau pembaruan tidak simplistis dan parsial, harus diuraikan juga pengertian modern, modernisme dan neomodernisme. Kata "modern" mengandung beberapa arti, di antaranya "zaman" (sejak tahun $1500 \mathrm{M}$ sampai sekarang) dan mengadaptasi metode, ide dan teknik mutakhir. Kata "modern" berasal dari bahasa Latin, modernus, yang diambil dari kata modo yang berarti "baru saja" dan "sekarang ini". Peradaban modern ditandai oleh dua ciri utama, yaitu rasionalisasi (cara berpikir rasional) dan teknikalisasi (cara bertindak secara teknis/mekanis) (Rumadi, 2007: 13). 
Modernisme diartikan sebagai pandangan atau metode modern, khususnya kecenderungan untuk menyesuaikan tradisi dan keyakinan agama agar harmonis dengan pemikiran modern. Kamus Webster mengartikan modernisme sebagai gerakan untuk mengadaptasi agama kepada pemikiran modern, khususnya untuk mengurangi elemen supranatural yang dianggap tradisional. Dengan demikian, gerakan modernisme Islam dapat dipahami sebagai gerakan yang muncul pada periode sejarah Islam akhir dengan mengadaptasi ajaran Islam terhadap pemikiran dan kelembagaan modern (Kurnia dan Fauzia dalam Abdullah, 2003: 349). Harun Nasution (1919-1998), tokoh pembaruan pemikiran Islam IAIN (sekarang UIN) Syarif Hidayatullah Jakarta, cenderung menghindari istilah modernisme dan lebih memilih kata "pembaruan". Kata modernisme menurutnya lebih banyak mengandung arti negatif di samping juga ada arti positifnya. Arti negatif yang dimaksud Nasution (1992) adalah kecenderungan adanya konotasi Barat yang ada pada kata tersebut, karena dapat muncul kesan bahwa modernisme Islam merupakan kelanjutan dari modernisme yang tumbuh di Barat.

Neo-modernisme merupakan sebuah tipologi pemikiran yang dibuat oleh Fazlur Rahman untuk menggambarkan perkembangan dan corak intelektualisme Islam. Rahman membagi gerakan pemikiran Islam dalam empat kategori. Pertama, gerakan revivalis di akhir abad 18, yang ditandai dengan munculnya gerakan Wahabiyah di Arab, Sanusiyah di Afrika Utara dan Fulaniyah di Afrika Barat. Gerakan ini belum bersentuhan dengan Barat. Kedua, modernisme klasik, yang muncul pada pertengahan abad 19 dan awal abad ke-20 yang sangat dipengaruhi oleh gagasan-gagasan Barat. Gerakan ini memberi perluasan isi pada ijtihad seperti hubungan akal dengan wahyu, pembaruan sosial terutama dalam bidang pendidikan, status perempuan, pembaruan politik dan bentuk-bentuk pemerintahan yang demokratis. Ketiga, neo-revivalis, gerakan ini mendasari dirinya pada basis pemikiran modernisme klasik bahwa Islam melingkupi seluruh aspek kehidupan manusia, baik individu maupun kolektif. Namun sebagai usaha untuk membedakan diri dari Barat, mereka tidak menerima metode dan semangat modernisme klasik meskipun mereka tidak mampu mengembangkan metodologi apapun untuk menegaskan posisinya. Keempat, neo-modernisme yang berusaha mencari sintesis progresif dari rasionalitas modernis dengan ijtihad dengan tradisi klasik (Rahmân, 1989: 17-21; Barton, 1999).

Bagi Nurcholish Madjid, atau yang akrab dipanggil Cak Nur, menyatakan bahwa modernisasi sebagai rasionalisasi, yaitu proses perombakan pola berpikir dan tata kerja lama yang tidak rasional lalu menggantinya dengan pola berpikir dan tata kerja baru yang rasional (Madjid, 2008: 180). Konstruksi berpikir seseorang yang sering menjadi acuan dalam adanya perombakan gagasan, sering kali menjadi faktor penentu dalam rangka melahirkan proses pembaruan secara simultan. Adanya proses pembaruan tentu saja akan meniscayakan aktivitas yang selalu diikuti dengan cara berpikir rasional, progresif dan dinamis.

Merujuk dari beberapa pengertian di atas, nampaknya ada beberapa 
komponen yang menjadi ciri suatu aktivitas ketika dikatakan sebagai aktivitas pembaruan, antara lain: pertama, baik pembaruan maupun modernisasi akan selalu mengarah kepada upaya perbaikan secara simultan, kedua, dalam upaya melakukan suatu pembaruan akan meniscayakan pengaruh yang kuat adanya ilmu pengetahuan dan teknologi, ketiga, upaya pembaruan biasanya dilakukan secara dinamis, inovatif dan progresif sejalan dengan perubahan cara berpikir (mindset) seseorang. Dengan demikian, ketika dihubungkan dengan modernisasi dalam pendidikan Islam akan memunculkan pengertian, sebagai suatu upaya melakukan proses perubahan kurikulum, cara, metodologi, situasi dan kondisi pendidikan Islam dari yang tradisional (orthodox) ke arah yang lebih rasional serta profesional sejalan dengan perkembangan ilmu pengetahuan dan teknologi saat seperti sekarang ini. Pengertian tersebut, sesungguhnya lebih dimaksudkan untuk dihadapkan dengan fakta empiris bahwa pendidikan Islam itu masih tradisional, lamban, statis, masih belum mampu menyiapkan generasi yang handal dan belum siap menghadapi tuntutan zaman.

Kerangka dasar yang berada di balik "pembaruan Islam" secara keseluruhan mencerminkan "pembaruan" pemikiran dan kelembagaan Islam sebagai prasyarat bagi kebangkitan kaum Muslim di masa modern (Azra, 2000: 31). Intinya, tanpa adanya perombakan pemikiran, tidak akan bisa terwujud bentuk-bentuk pembaruan yang lain, seperti halnya dengan bidang pendidikan Islam. Para pemikir Muslim dan para pengamat sosial-keagamaan Islam menggarisbawahi perlunya meneliti dan mencermati kembali prinsip-prinsip dasar, nilai-nilai dan norma-norma keislaman yang hendak dihidupkan kembali dalam era modernitas. Setidaknya, mereka sepakat bahwa tidak semua bentuk historisitas kelembagaan agama Islam era klasik-skolastik perlu dipertahankan begitu saja apa adanya, tanpa mempertanyakan secara kritis dan mempertanggungjawabkan nilai dan manfaat apa yang dapat dipetik dari upaya pelestarian bentuk historisitas kelembagaan tersebut. Beberapa istilah yang cukup dikenal di Indonesia antara lain adalah "reinterpretasi" (penafsiran ulang), "reaktualisasi" (mengangkat dan menghidupkan kembali), "reorientasi" (memikirkan kembali), "revitalisasi" (membangkitkan kembali), "kontekstualisasi" (mempertimbangkan konteks kehidupan sosial-budaya), "membumikan Islam", "pembaruan pemikiran Islam" dan "pembaruan Teologi Islam". Istilah-istilah lain yang masih mempunyai kandungan makna yang relatif sama adalah "Islam rasional", "Islam intelektual", "Islam substansial", "Islam transformatif" dan "Islam kontekstual" (Abdullah, 2006: 247).

Tema sentral ide pembaruan pemikiran dalam Islam terletak pada kata kunci I'âdatul Islâm, yakni keinginan masyarakat Muslim untuk mengembalikan peran dunia Islam dalam percaturan global peradaban dunia. Jika dahulu kebudayaan Islam pernah memberikan andil dalam mengukir perjalanan sejarah dunia selama 7 abad (dari abad ke-7 sampai abad ke-14), dan kemudian tenggelam dalam masa 5 abad terakhir (abad ke-15 sampai dengan abad ke-19), mengapa mereka tidak dapat menyumbangkan kembali sesuatu kepada 
peradaban dunia sekarang ini? Dengan semangat I'adatul Islam tersebut dan memerhatikan beberapa faktor yang menjadi sebab lahirnya pembaruan pendidikan Islam, maka pada garis besarnya telah terjadi dua pemikiran pembaruan pendidikan Islam, kedua pola tersebut adalah: 1) pola pembaruan pendidikan Islam yang berorientasi pada pola pendidikan modern di Barat, yang kemudian dikenal dengan gerakan modernis; dan 2) pembaruan pendidikan Islam yang berorientasi pada tujuan pemurnian kembali ajaran Islam.

Golongan pertama adalah golongan yang berorientasi pada pola pendidikan modern di Barat berpandangan bahwa sumber kekuatan dan kesejahteraan hidup yang diakui oleh Barat adalah dengan jalan mendirikan sekolah-sekolah ala Barat, baik sistem maupun isi pendidikannya. Dalam rangka memajukan sistem pendidikan Islam, banyak juga pelajar yang dikirim ke Eropa terutama Perancis, untuk menguasai ilmu-ilmu sains dan teknologi modern. Kelompok ini telah menyadari bahwa kondisi pendidikan Islam telah mengalami kemunduran yang sangat luar biasa. Pendidikan Islam atau institusi madrasah, tidak lagi bisa dipandang sebagai institusi alternatif yang bisa mencetak para lulusan yang handal. Oleh karenanya adanya usaha perbaikan sistem, tujuan, metodologi, prasarana dan sarana ke arah pendidikan yang lebih baik yang kini sudah menjadi satu kebutuhan bagi para pembaru Islam. Bagi kelompok ini, langkah pertama yang harus dilakukan adalah bagaimana umat Islam bisa belajar dari Barat, dalam pengertian menggali segala ilmu pengetahuan yang mereka miliki, tidak bosan menggali banyak informasi dari mana pun, sehingga ketertinggalan-ketertinggalan yang selama ini dirasakan, paling tidak, bisa terminimalisir. Kelompok "pendidikan Barat" ini menekankan perlunya Tajdìd alFabm (memperbaharui pemahaman Islam). Bagi pendukung aliran pemikiran ini, tampaknya, ada "something wrong" yang melekat dalam pemahaman orang-orang Islam terhadap ajaran-ajaran pokok Islam. Generasi Muslim terdahulu, khususnya generasi Muslim 5 abad terakhir, terpaku pada patokan-patokan historisitas undang-undang fiqih yang rigid, dan terpola oleh pemikiran Kalam yang bersifat klasik-skolastik (Arkoun, 1990: 172-173). Padahal semua "mode of thought' pemikiran keislaman klasik itu, dulunya juga disusun, dikonsepsikan dan diciptakan oleh keprihatinan historis yang dihadapi oleh generasi tertentu pada zamannya. Anehnya, generasi yang datang berikutnya, tidak mampu ke luar dari garis batas lingkaran yang mereka buat sendiri. Mereka tidak bisa bebas bergerak, berkreasi dan berargumentasi menatap perubahan zaman yang dimotori oleh penemuan-penemuan ilmu dan teknologi (Abdullah, 2006: 250). Alur model pemikiran pembaruan keislaman yang pertama ini dimotori oleh Muhammad Abduh. Baginya, kebudayaan jauh lebih luas daripada fiqih, aqidah maupun akhlak. Kebudayaan mencakup wilayah natural sciences dan bumanities. Kebudayaan mencakup sejarah, filsafat, seni juga sains dan teknologi. Maka ketika Abduh memulai mengajar di al-Azhar, materi perkuliahan yang diajarkan agak aneh dan menyimpang dari tradisi keilmuan Islam klasik yang berjalan sampai saat itu. Ia mengajarkan Sejarah Kebudayaan Eropa (Kebudayaan Perancis, khususnya), 
filsafat dan logika serta sosiologi (Amin, t.th.: 292-293). Dari sini muncul berbagai istilah seperti reinterpretasi, reaktualisasi, reorientasi dan kontekstualisasi terhadap nilai-nilai dan prinsip-prinsip dasar keberagamaan Islam (Abdullah, 2006: 250).

Kedua, golongan yang berorientasi pada pembaruan pendidikan Islam yang berdasarkan sumber Islam yang murni. Bagi mereka, terjadinya kemunduran umat Islam lebih disebabkan oleh ketidaktaatan kaum muslimin dalam menjalankan ajaran Islam sebagaimana mestinya. Pola ini berpandangan bahwa sesungguhnya Islam sendiri merupakan sumber bagi kemajuan dan perkembangan peradaban serta ilmu pengetahuan modern, dalam hal ini Islam telah membuktikannya pada masa kejayaan di masa silam (Zuhairini, 1992: 110). Bagi kelompok ini, adanya kemajuan peradaban dan ilmu pengetahuan yang pernah dialami umat Islam seharusnya menjadi referensi atau bahkan sandaran kalau sesungguhnya Islam sendiri, melalui ajarannya yakni al-Qur'an dan hadis bisa memajukan umatnya tanpa harus berkiblat kepada Barat. Justru umat Islam harus kembali menengok masa-masa silam kejayaannya, bukan berbalik memalingkan atau tidak mau menengok sama sekali ke belakang. Demikian pendapat kelompok tradisionalis.

Para pendukung pemikiran yang kedua ini, sama-sama melihat adanya "something wrong" yang dilakukan oleh generasi Muslim terdahulu, khususnya, selama 5 abad terakhir, sehingga mereka jatuh kepada belenggu imperialismekolonialisme. Kata kunci yang diajukan sebagai upaya penyembuhan penyakit kronis tersebut adalah Tathbîq al-syari'ah, atau Tathbîq qanûni al-syarîah, yakni dengan cara mengaplikasikan kembali atau mempraktikkan kembali materi undang-undang dan tata cara kenegaraan yang pernah dilakukan oleh generasi Muslim terdahulu.

Dalam praktiknya, biasanya, program tersebut hanya fokus pada undangundang syari'ah dalam arti sempit, yakni hukum-hukum fiqih siyasah yang pernah berlaku pada era terdahulu untuk diterapkan kembali pada era modern sekarang secara lebih tepat. Pemahaman mereka terhadap ayat-ayat al-Qur'an cenderung bercorak tekstualis, sehingga apa yang terbaca dalam al-Qur'ân dan hadis ingin diaplikasikan begitu saja apa adanya pada era sekarang tanpa mempertimbangkan lebih jauh perbedaan kondisi dan situasi sejarah serta perkembangan cara berpikir dan kebudayaan manusia itu sendiri. Alur pemikiran ini dimotori oleh M. Rasyid Ridha (1865-1935) yang juga adalah salah seorang murid Abduh, namun lebih dipengaruhi oleh pemikiran Ibn Taimiyyah (wafat 1328) (Abdullah, 2006: 252).

\section{Modernisasi Pendidikan Islam Menurut Muhammad Abduh}

Latar belakang munculnya pembaruan dalam bidang pendidikan Islam antara lain adanya situasi sosial keagamaan masyarakat Mesir saat itu yang penuh dengan taqlìd, bid'ah dan khurafat serta pemikiran yang statis. Seperti halnya AlAfghani, Abduh melihat bahwa salah satu penyebab keterbelakangan umat Islam 
yang amat memprihatinkan adalah hilangnya tradisi intelektual yang pada intinya ialah kebebasan berpikir (Madjid, 2008: 367). Pendidikan pada umumnya tidak diberikan kepada kaum wanita sehingga wanita tetap dalam kebodohan dan penderitaan. Abduh berpandangan bahwa penyakit tersebut antara lain berpangkal dari ketidaktahuan umat Islam pada ajaran agama yang sebenarnya, karena mereka mempelajari dengan cara yang tidak tepat. Menurut Abduh, penyakit tersebut dapat diobati dengan cara mendidik mereka dengan sistem pengajaran yang tepat (Darmu'in, 1999: 187).

Sistem pendidikan yang ada pada saat itu melatarbelakangi pemikiran modernisasi pendidikan Muhammad Abduh. Sebelumnya, pembaruan pendidikan Mesir diawali oleh Muhammad Ali. Dia hanya menekankan pada perkembangan aspek intelektual dan mewariskan dua tipe pendidikan pada masa berikutnya. Model pertama ialah sekolah-sekolah modern, sedangkan model kedua adalah sekolah agama. Masing-masing sekolah berdiri sendiri, tanpa mempunyai hubungan satu sama lain. Pada sekolah agama tidak diberikan pelajaran ilmu-ilmu modern yang berasal dari Barat sehingga perkembangan intelektual berkurang. Sedangkan pada sekolah-sekolah yang diselenggarakan oleh pemerintah, hanya diberikan ilmu pengetahuan Barat, tanpa memberikan ilmu agama (Darmu'in, 1999: 188).

Pada periode ini pula terdapat dualisme pendidikan yang memunculkan dua kelas sosial berbeda. Pertama adalah sekolah yang menghasilkan ulama dan tokoh masyarakat yang enggan menerima perubahan dan mempertahankan tradisi. Kedua adalah sekolah yang menghasilkan kelas elit. Generasi muda yang dimulai pada abad 19, dengan ilmu-ilmu Barat yang mereka peroleh, membuat mereka dapat menerima ide-ide Barat. Abduh melihat segi negatif dari dua model pendidikan tersebut sehingga mendorongnya untuk mengadakan perbaikan pada dua instansi tersebut (Kurniawan dan Mahrus, 2011: 123).

Bagi Abduh, apa yang dibutuhkan oleh umat Muslim sehubungan dengan datangnya era modernisme adalah memformulasikan sebuah cetak-biru (blue print) yang praktis-aplikatif sebagai fondasi epistemologis keyakinan umat Muslim yang diciptakan melalui ruang-ruang pendidikan. Cetak biru semacam ini diharapkan mampu mengatasi berbagai persoalan yang muncul akibat era modernisme ini, seperti persoalan ontologis, epistemologis dan aksiologis. Sebagai seorang pembaharu dalam pendidikan Islam, ada beberapa masalah yang ia temukan di lapangan yang menurutnya menyimpang dan menjadi penyebab kemunduran umat Islam kala itu bahkan menjauhkan umat Islam dari eksistensi kedirian mereka. Karena itu, menurut Abduh yang harus dilakukan adalah Tajdîd al-Fahm (memperbarui pemahaman tentang Islam) dalam arti bahwa nilai-nilai dan prinsip-prinsip dasar keberagamaan Islam yang esensial saja yang perlu dipertahankan dan diaktualkan, sedangkan aspek historisitas kelembagaannya tidak harus dipertahankan, sebab berhubungan dengan ruang dan waktu yang terus berubah. Dalam konteks ini modernisasi yang dilakukan Abduh dalam bidang pendidikan Islam meliputi; 
1. Tujuan pendidikan.

Dalam merumuskan tujuan pendidikan, Abduh selalu menghubungkan antara tujuan yang satu dengan lainnya, baik tujuan akhir maupun tujuan institusional. Pokok pikirannya tentang tujuan institusional pendidikan didasarkannya kepada tujuan pendirian sekolah. Ia membagi jenjang pendidikan kepada tiga tingkatan, yaitu (a) Tingkat Dasar (mubtadi'in), (b) Tingkat Menengah (thabaqât al-wustha), dan (c) Tingkat Tinggi (thabaqât al-'Ulyâ). Pada pendidikan tingkat dasar, tujuan institusionalnya adalah pemberantasan buta huruf, sehingga murid mampu membaca teks yang tersurat dan dapat berkomunikasi melalui tulisan. Mereka juga diharapkan bisa berhitung sehingga dapat menunjang kegiatan sehari-hari mereka sebagai petani, pedagang, pengusaha, pegawai maupun sebagai guru dan pemimpin. Di samping anak bisa menulis, membaca dan berhitung diharapkan agar setelah anak didik menyelesaikan studinya di sekolah tingkat dasar juga sudah mempunyai dasar-dasar ilmu pengetahuan agama yang kuat dan dapat pula mengamalkan pokok-pokok ajaran agama, sesuai dengan kemampuan intelektualnya (Imarah, 1972: 76).

Pendidikan tingkat menengah bertujuan untuk mendidik anak agar kelak mereka dapat bekerja sebagai pegawai pemerintah, baik sipil maupun militer. Mereka diharapkan oleh negara untuk menjadi orang-orang yang dapat dipercaya dan bertanggung jawab terhadap tugas-tugas yang dibebankan kepadanya. Misalnya tentara, mereka dipersiapkan untuk menjadi prajurit yang tangguh yang memanggul senjata dan dengan gagah berani menghadapi musuh. Untuk hakim, mereka dipersiapkan dapat menyelesaikan kasus-kasus pertikaian yang terjadi dalam masyarakat dan menghukumnya secara adil berdasarkan undang-undang, membenarkan yang benar dan menyalahkan yang salah. Lulusan tingkat menengah ini diharapkan dapat mendahulukan kepentingan dan kemaslahatan umum di samping kepentingan mereka sendiri serta berusaha untuk mewujudkan masyarakat sejahtera (Imarah, 1972: 79).

Adapun tujuan pendidikan tingkat tinggi adalah untuk mencetak tenaga guru dan pemimpin-pemimpin masyarakat yang berkualitas. Mereka yang telah berhasil menyelesaikan studinya di sekolah tingkat tinggi ini diharapkan dapat menjadi guru untuk seluruh jenjang pendidikan (Khoury, 1986: 166). Selain menjadi guru, mereka juga diharapkan dapat membina kesejahteraan masyarakat. Menurut Abduh tujuan pendidikan adalah mendidik akal dan jiwa serta menyampaikannya pada batas-batas kemungkinan seorang mencapai kebahagiaan di dunia dan di akhirat (Ridha, 1931: 17). Tujuan pendidikan yang dirumuskan Abduh tersebut mencakup aspek akal dan aspek spiritual. Dengan tujuan tersebut, ia menginginkan terbentuknya pribadi yang mempunyai struktur jiwa yang seimbang yakni tidak hanya menekankan pengembangan akal tetapi juga pengembangan spiritual. Abduh berkeyakinan bahwa apabila aspek akal dan spiritual dididik dan dicerdaskan dengan cara agama maka umat Islam akan dapat bersaing dalam menguasai dan mengembangkan ilmu pengetahuan serta dapat mengimbangi mereka dengan kebudayaan yang tinggi (Lubis, 1993: 156). Bagi 
Abduh pendidikan yang baik adalah pendidikan yang dalam prosesnya mampu mengembangkan seluruh fitrah peserta didik terutama fitrah akal dan agamanya. Dengan fitrah akal, peserta didik akan dapat mengembangkan daya berpikir secara rasional. Melalui fitrah agama akan tertanam pilar-pilar kebaikan pada diri peserta didik yang selanjutnya berdampak pada seluruh aktivitas hidupnya (Abduh: 1972: 117).

2. Kurikulum sekolah.

Kurikulum yang dirumuskan Abduh meliputi; (a) untuk tingkat sekolah dasar; membaca, menulis, berhitung dan pelajaran agama dengan materi aqidah, fiqih, akhlaq dan sejarah Islam; (b) untuk tingkat menengah; manthiq dan dasar penalaran, aqidah yang dibuktikan dengan akal dan dalil-dalil yang pasti, fiqih dan akhlaq serta sejarah Islam; (c) untuk tingkat atas; tafsir, hadis, bahasa Arab dengan segala cabangnya, akhlak dengan pembahasan yang rinci, sejarah Islam, retorika dan dasar-dasar berdiskusi serta ilmu kalam (Kurniawan dan Mahrus, 2011: 124).

Dari penerapan kurikulum di atas, tampak bahwa 'Abduh ingin menghilangkan dualisme pendidikan yang ada pada saat itu. Dia menginginkan sekolah-sekolah umum memberikan pelajaran agama dan al-Azhar diharapkan menerapkan ilmu-ilmu yang datang dari Barat. Dalam penyusunan materi ini ia selalu merujuk kepada tujuan pendidikan yang titik sentralnya adalah mencapai tujuan akhir pendidikan Islam ke arah pengembangan yang seimbang antara akal dan jiwa guna mencapai kebahagiaan di dunia dan di akhirat.

Materi kurikulum yang ditawarkannya adalah Akidah Islam, Fiqih dan Akhlak, dan Sejarah (Sahrah, t.th.: 6). Akidah Islam yang disajikan berupa ringkasan akidah Islam yang disepakati oleh Abl as-sunnah, bukan aqidah yang mengandung kontradiktif antara golongan. Penyajian pelajaran harus berdasarkan kepada al-Qur'an dan hadis. Selain akidah Islam, sebagai perbandingan, diajarkan pula akidah Kristen beserta kekacauan dan kesamaran ajarannya. Dengan cara demikian diharapkan anak didik dapat tumbuh keyakinannya terhadap kebenaran ajaran Islam dan menolak ajaran Kristen (Ridha, 1931: 513). Materi yang kedua adalah Fikih dan Akhlak. Pada tingkat dasar ini pelajaran fiqih meliputi masalah halal dan haram, ibadah yang asli dengan ibadah yang bid'ah serta masalah wajib dan sunat. Semua materi harus berdasarkan pada al-Qur'an, hadis dan pendapat sahabat. Dari sumber materi pelajaran fiqih di atas terlihat bahwa Abduh tidak berpegang kepada pendapat madzhab. Dalam pelajaran akhlak diajarkan tentang akhlak terpuji dan akhlak tercela. Tujuan diajarkan materi tersebut adalah untuk menumbuhkan rasa kesadaran diri anak didik bahwa mereka adalah makhluk yang diciptakan oleh Tuhan. Sebagai makhluk yang diciptakan Tuhan, mereka diberi kebebasan dengan batas-batas tertentu. Oleh karena itu, mereka harus tunduk dan patuh kepada perintah dan larangan yang telah ditetapkan-Nya (Ridha, 1931: 512). Materi yang ketiga adalah Sejarah Islam. Pelajaran sejarah Islam pada tingkat ini 
disajikan dalam bentuk ringkasan, sehingga anak didik dapat mengerti dan memahaminya dengan baik sesuai dengan tingkat kemampuan mereka dan tingkat pendidikan yang mereka tempuh (Ahmad, 1981: 148). Dalam kurikulum tingkat menengah, Abduh menawarkan beberapa mata pelajaran yang harus diajarkan pada anak didik, yaitu Ilmu logika (fann al-manthiq), dasar-dasar penalaran (al-ushôl an-nazhari) dan ilmu debat atau diskusi (adâb al-jadal). Ketiga pelajaran di atas tidak dapat dipisahkan, namun sebagai dasarnya adalah ilmu logika (Ridha, 1931: 513).

Abduh tidak menjelaskan tentang tujuan diajarkannya ilmu tersebut namun nampak bahwa pada tingkat menengah ini Abduh telah mulai mengarahkan pendidikan Islam ke arah pendidikan akal, yaitu melatih anak didik atau membekali mereka dengan ilmu-ilmu yang mengajak kepada berpikir kritis, dengan begitu, sikap taqlìd yang sudah menyebar tidak akan merembes kepada anak didik sebagai generasi muda (Sahrah, t.th.: 8).

Pada kurikulum pendidikan tinggi, Abduh menawarkan materi-materi Tafsir al-Qur'an al-Karîm, Hadis, Bahasa Arab, Ushûl Fiqih, Pelajaran Akhlak, Sejarah Islam, Retorika dan Dasar-dasar Diskusi, dan Ilmu Kalâm. Abduh mengatakan, di dalam al-Qur'an terdapat rahasia-rahasia kesuksesan umat Islam terdahulu. Oleh karena itu agar umat Islam sekarang bisa sukses, mereka harus mempelajari secara mendalam tentang al-Qur'an beserta metode penafsirannya, serta ilmu-ilmu alat lain (Ridha, 1931: 515).

3. Metode pengajaran.

Abduh menekankan pemberian pengertian (pemahaman) dalam setiap pelajaran yang diberikan. Ia mengingatkan kepada para pendidik untuk tidak mengajar murid dengan metode hafalan, karena metode hafalan menurutnya hanya akan merusak daya nalar (Darmu'in, 1999: 311). Abduh menekankan metode diskusi untuk memberikan pengertian yang mendalam kepada murid (Lubis, 1993: 160). Metode yang dipakai Abduh dalam mengajar dimaksudkan untuk mendukung pencapaian tujuan pendidikan yang diinginkannya, yaitu pengembangan kemampuan intelektual anak didik, karena dengan metode tersebut akan memupuk keberanian anak didik untuk mengemukakan pendapat dan membantah pendapat orang lain jika tidak sesuai dengan pendapatnya. Hal ini yang membuat Abduh ingin mengubah metode mengajar yang digunakan pada waktu itu dengan metode yang lebih kompleks dan efektif.

Selain memakai metode di atas ia juga mengembangkan metode latihan dan pengalaman, metode keteladanan dan cerita. Karena menurutnya anak didik perlu dilatih untuk beribadah, bahkan kalau perlu guru harus memperagakannya di depan kelas sebagai contoh pelaksanaan ibadah shalat (Ridha, 1931: 81). Bagaimanapun juga, menggalakkan metode keteladanan merupakan upaya paling efektif dalam menanamkan nilai-nilai moral pada guru agar perbuatan mereka dapat dijadikan panutan oleh anak didik. Oleh karena itu Abduh memberikan kriteria yang ketat dalam pemilihan kepala sekolah dan guru (Ridha, 1931: 549). 
Mereka harus orang yang melaksanakan ajaran agama tersebut dalam kehidupan sehari-hari, baik dalam hubungannya dengan Allah maupun sesama makhluk. Untuk mendukung metode tersebut, ia memadukannya dengan metode cerita yaitu dengan memberikan materi sejarah tentang kisah-kisah perjalanan dan perjuangan Nabi, sahabat, tabi'in dan ulama-ulama terdahulu. Metode ini bertujuan membangkitkan semangat untuk memberikan dorongan psikologis kepada anak didik.

\section{Pendidikan bagi perempuan.}

Menurut Abduh, pendidikan harus diikuti oleh semua orang, baik laki-laki maupun perempuan. Menurutnya perempuan harus mendapat hak yang sama dalam bidang pendidikan. Hal ini didasarkan kepada QS. Al-Baqarah [2]: 228 dan QS Al-Ahzâb [33]: 35 (Kurniawan dan Mahrus, 2011: 124).

Menurut Harun Nasution, gagasan memperjuangkan pendidikan bagi kaum wanita pada Islam modern di Mesir ini, untuk pertama kalinya digagas oleh Rifa'ah at-Tahtawi (1801-1873) agar wanita Mesir memperoleh pendidikan yang sama dengan pria (Nasution, 1992: 48). Tujuannya agar wanita Mesir dapat menjadi isteri yang baik, dapat menjadi teman suami dalam kehidupan intelek dan sosialnya serta dalam rangka membentuk kepribadian dan menanamkan rasa patriotisme atau Hubb al-Wathan. Gagasan tersebut dipertegas oleh Muhammad Abduh. Menurut Abduh, wanita, dalam Islam sebenarnya mempunyai kedudukan yang tinggi, tetapi adat istiadat yang berasal dari luar Islam mengubah hal tersebut sehingga wanita Islam mempunyai kedudukan rendah dalam masyarakat (Nasution, 1992: 79). Ide ini kemudian dibahas panjang lebar oleh Qosim al-Amin (1865-1908) dalam bukunya Tahrîr al-Mar'ah (kebebasan wanita) terbit tahun 1900 dan al-Mar'at al-Jadìdah (wanita modern) terbit tahun 1901. Menurut Qosim Amin, umat Islam mundur karena kaum wanita (setengah dari jumlah penduduk Mesir) tidak pernah memperoleh pendidikan sekolah. Pendidikan wanita itu perlu. Hal tersebut bukan hanya agar wanita dapat mengatur rumah tangga, melainkan juga agar mereka dapat memberikan pendidikan dasar bagi putra-putri mereka. Ide ini kemudian diteruskan oleh Thoha Husein (1899-1973) dan pada masanya (1954) wanita telah diizinkan kuliah di al-Azhar. Dengan demikian, gagasan memperjuangkan pendidikan wanita pada masa Islam modern menunjukkan adanya kesinambungan organik yang tidak terputus dari para pemikir sebelumnya sampai didirikannya akademi wanita di kompleks al-Azhar (Ihsan, 2007: 12).

Nilai-nilai pendidikan Islam yang ingin ditegakkan Muhammad Abduh yaitu; (1) Nilai persatuan dan nilai solidaritas, yaitu usaha yang dilakukan Abduh guna memulihkan kembali kekuatan Islam dengan membentuk al-Urwat alWutsqâ di bawah panji bersama dengan semangat ukhuwah Islamiyab; (2) Nilai pembaruan (tajdîd). Abduh berusaha mencanangkan gerakan pembaruan, berusaha membuka pemikiran di kalangan umat Islam yang beranggapan pintu ijtihâd telah tertutup sehingga menjadi taqlîd; (3) Nilai perjuangan (al-jïhâd fî 
sabîlillâh), yaitu gerakan yang dicanangkan Abduh baik dalam politik secara diplomatis maupun dalam bidang pendidikan dan sosial mengandung unsur perjuangan untuk membela Islam; (4) Nilai-nilai kemerdekaan (burriyah). Abduh berusaha membuka pemikiran (bebas mengemukakan pemikiran) umat Islam yang selama ini terlalu bergantung dengan pemerintah dan terbelenggu dengan pemikiran sempit yang statis (Kurniawan dan Mahrus, 2011: 125). Pemikiran Muhammad Abduh tentang pendidikan dinilai sebagai awal dari kebangkitan umat Islam di awal abad ke-20. Pemikiran Muhammad Abduh yang disebarluaskan melalui tulisannya di majalah al-Manar dan al-Urwat al-Wutsqâ menjadi rujukan para tokoh pembaharu dalam dunia Islam, hingga di berbagai negara Islam muncul gagasan mendirikan sekolah-sekolah dengan menggunakan kurikulum seperti yang dirintis Abduh (Ramayulis dan Samsul Nizar, 2009: 297).

\section{SIMPULAN}

Memudarnya nilai-nilai pendidikan Islam sesungguhnya lebih dilatarbelakangi oleh kondisi internal Islam yang tidak lagi menganggap ilmu pengetahuan umum sebagai satu kesatuan ilmu yang harus diperhatikan. Justru ilmu pengetahuan lebih banyak diadopsi bahkan dimanfaatkan secara komprehensif oleh Barat. Inilah awal mula terjadinya kesadaran umat Islam akan ketertinggalannya yang begitu jauh. Bagi Abduh, apa yang dibutuhkan oleh umat Muslim terkait dengan datangnya era modernisme adalah memformulasikan sebuah cetak-biru (blue print) yang praktis-aplikatif sebagai fondasi epistemologis keyakinan umat Muslim yang diciptakan melalui ruang-ruang pendidikan. Cetak biru semacam ini diharapkan mampu mengatasi berbagai persoalan yang muncul akibat era modernisme ini, seperti persoalan ontologis, epistemologis dan aksiologis keilmuan Islam. Abduh mengatakan bahwa umat Islam harus melakukan Tajdìd al-Fahm (memperbaharui pemahaman Islam) dalam arti bahwa nilai-nilai dan prinsip-prinsip dasar keberagamaan Islam yang esensial saja yang perlu dipertahankan dan diaktualkan, sedangkan aspek historisitas kelembagaannya tidak harus dipertahankan, karena senantiasa berhubungan dengan ruang dan waktu yang terus berubah. Meski Abduh belum sempat merealisasikan pokokpokok pemikirannya dikala ia masih hidup, namun 'Abduh telah meletakkan fondasi yang kuat ke arah perbaikan dan pembaruan pendidikan Islam. selanjutnya umat Islam generasi berikutnya yang meneruskan penciptaan tatanan dunia pendidikan yang seimbang dan harmonis sesuai tuntutan dunia modern sekarang dan yang akan datang. Abduh ingin menghilangkan dualisme pendidikan yang ada pada saat itu. Dia menginginkan sekolah-sekolah umum memberikan pelajaran agama dan al-Azhar menerapkan ilmu-ilmu yang datang dari Barat. Dalam penyusunan materi ini harus merujuk kepada tujuan pendidikan yaitu pengembangan yang seimbang antara akal dan jiwa guna mencapai kebahagiaan di dunia dan di akhirat. 


\section{DAFTAR PUSTAKA}

Abduh, Muhammad. 1972. "Al-Madâris al-Tajhizât wa al-Madâris al-Aliyât" dalam Imarah, al-A'mâl al-Kâmil Li al-Imâm Muhammad 'Abduh, juz III. Beirut: al-Muassasah al-Arabiyah li al-Dirasah wa al-Nashr.

Abdullah, M. Amin. 2006. Islamic Studies di Perguruan Tinggi Pendekatan IntegratifInterkonektif. Yogyakarta: Pustaka Pelajar.

Abu Bakar, M. Yunus. 2012. "Pengaruh Paham Liberalisme dan Neoliberalisme Terhadap Pendidikan Islam di Indonesia." Jurnal Tsaqafah 8,1,

Ahmad, Muhammad abd Al-Qadir. 1981. Thuruq at-Tarbiyât al-Islâmiyah. Mesir: Maktabah an-Nahdah.

Ahmed, Akbar S. 1999. Discovering Islam: Making Sense of Muslim History and Society. London \& New York: Routledge.

Amin, Ahmad. T.th. Zu'amau al-Islah fi al-Asri al-Hadits. Beirut: Dar al-Kitab alArby.

Amin, Ahmad. 1960. Muhammad Abduh. Kairo: AL Khanji.

A.N, Firdaus. 1979. Syaikh Mubammad Abdub dan Perjuangannya. Jakarta: Bulan Bintang.

Arkoun, Mohammed. 1990. Al-Islâm: al-Akblâq wa al-Siyâsah, terj. dari bahasa Perancis oleh Hashim Saleh. Beirut: Markaz al-inma' al-Qaumi.

Asrahah, Hanun. 1999. Sejarah Pendidikan Islam. Jakarta: Logos.

Azra, Azyumardi. 2000. Pendidikan Islam: Tradisi dan Modernisasi Menuju Milenium Baru. Jakarta: Logos Wacana Ilmu.

Baidlawi, Moh. 2006. "Modernisasi Pendidikan Islam (Telaah Atas Pembaharuan Pendidikan di Pesantren)." Jurnal Tadrîs 1,2,.

Barton, Greg. 1999. Gagasan Islam Liberal di Indonesia, Pemikiran Neo-Modernisme Nurcholish Madjid, Djoban Effendi, Abmad Wabib dan AbdurRabmân Wabid. Jakarta: Paramadina.

Darmu'in. 1999. Pemikiran Pendidikan Islam: Kajian Tokoh Klasik dan Kontemporer. Yogyakarta: Pustaka Pelajar.

Gellner, Ernest. 1981. Muslim Society. Cambridge: Cambridge University Press.

Gellner, Ernest (Ed.). 1985. Islamic Dilemma: Reformers, Nationalists, and Industrialization. New York and Amsterdam: Walter de Gruyter.

Hasaruddin. 2012. "Pembaharuan Hukum Islam Menurut Pandangan Muhammad Abduh." Jurnal Al-Risalab 12,2,.

Hilmy, Masdar. 2012. "Nomenklatur Baru Pendidikan Islam di Era Industrialisasi." Jurnal Tsaqafah 8,1,.

Husein, Syed Sajjad dan Ashraf, Syed Ali. 1994. Menyongsong Keruntuban Pendidikan Islam, terj. Rahmâni Astuti. Bandung: Gema Risalah Press.

Ihsan, Muhammad. 2007. "Pendidikan Islam dan Modernitas di Timur Tengah: Studi Kasus Mesir.” Jurnal Hunafa 4,2,

Imarah, Muhammad. 1972. Al-A'mâl al-Kâmilah II al-Imâm Muhammad 'Abduh, jilid III. Beirut: al-Muassasah al-Arabiyah II al-Dirasah wa al-Nasyr.

Khoury, Nabil Abdo. 1986. Islam and Modernization in the Middle East, Mubammad 
Abduh an Ideology of Development. Michigan: University Microfilm International.

Kurnia, Nia dan Fauzia, Amelia. 2003. "Gerakan Modernisme," dalam Taufik Abdullah dkk (Ed.), Ensiklopedi Tematis Dunia Islam (Asia Tenggara). Jakarta: Ichtiar Baru van Hoeve.

Kurniawan, Syamsul dan Mahrus, Erwin. 2011. Jejak Pemikiran Tokob Pendidikan Islam. Yogyakarta: Ar-Ruzz Media.

Lubis, Arbiyah. 1993. Pemikiran Muhammadiyah dan Muhammad Abdub: Suatu Studi Perbandingan. Jakarta: Bulan Bintang.

Madjid, Nurcholish. 2008. Islam, Kemodernan, dan Keindonesiaan. Bandung: Mizan.

Muqoyyidin, Andik Wahyun. 2012. Universitas Islam Center of Excellences: Integrasi dan Interkoneksitas Ilmu-ilmu Agama dan Sains Menuju Peradaban Islam Kosmopolitan. Conference Proceedings Annual International Conference on Islamic Studies (AICIS) XII 5-8 November. Surabaya: IAIN Sunan Ampel.

Nasution, Harun. 1987. Muhammad Abduh dan Teologi Rasional Mu'tazilah. Jakarta: UI Press.

Nasution, Harun. 1992. Pembaharuan dalam Islam, Sejarah Pemikiran dan Gerakan. Jakarta: Bulan Bintang.

Nasution, Harun. 1997. Islam Rasional. Bandung: Mizan.

Rahmân, Fazlur. 1985. Islam and Modernity: Transformation of an Intelectual Tradition, terj. Ahsin Muhammad. Bandung: Pustaka.

Rahmân, Fazlur. 1989. Neomodernisme Islam, Metode dan Alternatif, ed. Taufik Adnan Amal. Bandung: Mizan.

Ramayulis, H. dan Nizar, Samsul. 2009. Filsafat Pendidikan Islam: Telaah Sistem Pendidikan dan Pemikiran Para Tokobnya. Yogyakarta: Kalam Mulia.

Ridha, Sayyid Muhammad Rasyid. 1931. Târikh al-Ustâdz al-Imâm al-Syaikh Munammad 'Abduh. Kairo: Percetakan al-Manâr.

Rumadi. 2007. Post-Tradisionalisme Islam: Wacana Intelektualisme dalam Komunitas NU. Jakarta: Direktorat Pendidikan Tinggi Islam DEPAG RI.

Sahrah, H. T.th. Antologi Tesis: Pemikiran Pendidikan Muhammad Abduh Sebagai Strategi Modernisasi. http://idb3.wikispaces.com (diunduh tanggal 14 April 2013).

Shihab, M. Quraish. 2006. Rasionalitas Al-Qur'ân: Studi Kritis atas Tafsir al-Manar. Jakarta: Lentera Hati.

Zuhairini. 1992. Sejarah Pendidikan Islam. Jakarta: Bumi Aksara. 